\title{
Yam-Based Cropping Systems Performances with Chemical Fertilizers
}

\author{
Raphiou Maliki ${ }^{*}$, Anne Floquet ${ }^{2}$, Kakaï Romain Glèlè ${ }^{3}$ and Brice Sinsin ${ }^{4}$ \\ ${ }^{1}$ Raphiou Maliki, PhD, National Institute of Agricultural Research of Benin (INRAB), Benin \\ ${ }^{2}$ Anne Floquet, PhD, Benin Center for Environment, Economic and Social Development (CEBEDES), Benin \\ ${ }^{3}$ Kakaï Romain Glèlè, Professor, Faculty of Agricultural Sciences of the University of Abomey-Calavi (FSA/UAC), Benin \\ ${ }^{4}$ Brice Sinsin, Professor, Faculty of Agricultural Sciences of the University of Abomey-Calavi (FSA/UAC), Benin
}

*Corresponding author: Raphiou Maliki, PhD, National Institute of Agricultural Research

of Benin (INRAB), Calavi, Benin.

Received Date: September 26, 2019

Published Date: September 30, 2019

\section{Introduction}

Yam (Dioscorea spp.) is a tuber crop widely cultivated in the humid and sub-humid lowland regions of West Africa and the Caribbean. More than $90 \%$ of the worldwide production ( 40 million metric tons of fresh tubers year-1) is produced in West Africa [1].

Yam cultivation in West Africa is now confronted with the scarcity of fertile soil available for clearing [2]. In Benin nowadays, farmers hardly have the possibility to rely on long duration fallow and yam is being cultivated in 1 or 2-year herbaceous fallow-yam or maize-yam rotation systems with manual incorporation of residue into the soil.

The decline in yam yields under continuous cultivation has led to the largely accepted conclusion that yam requires a high level of natural soil fertility (organic matter and nutrient) (O'Sullivan and Ernest, 2008). Since the demand for yam keeps increasing due to the continued population growth, reserves of arable land are diminishing, and fallow duration is decreasing. It is becoming necessary to sustainably increase yam productivity in sedentary cropping systems (O'Sullivan and Ernest, 2008). There is a dire need therefore to assess in farmers' conditions the economic performance of sustainable cultivation techniques. Ongoing soil degradation could be reduced by the adoption of new farming techniques such as improved fallows of herbaceous legumes $[3,4]$.

With the aim of designing more sustainable yam cropping systems, the agronomic research organization in Benin implemented alternative systems including herbaceous legumes. On the basis of the results of this on-farm research, yam-based systems including herbaceous legumes were diffused. A perennial experiment was implemented for 4 years, with 2-year rotations, smallholder farmers' traditional rotations maize-yam or 1-year Andropogonon gayanus fallow-yam, with rotations intercropped Aeschynomene histrix with maize-yam or intercropped Mucuna pruriens with maize and chemical fertilizers-yam.

\section{Materials and Methods}

The study was carried out in the Guinea-Sudan transition zone of Benin (centre of Benin) in four sites: Miniffi (District of DassaZoumè), Akpéro, and Gbanlin (Ouessè) on plateau, Gomè (Glazoué) in lowland, within latitude ranges $7^{\circ} 45^{\prime}$ to $8^{\circ} 40^{\prime}$ ' North and longitude ranges $2^{\circ} 20^{\prime}$ to $2^{\circ} 35^{\prime}$ East. The climate is tropical with a bimodal rainfall pattern.

The soils are plinthosols (Gbanlin and Akpéro), and luvisols (Miniffi and Gomè) [5]. Miniffi, Akpéro and Gbanlin are located on a plateau while Gomè is on lowland. Vegetation is a degraded woody savannah type. Maize, yam, cassava and groundnut are annual crops and the cash crops are cotton and soybean.

Smallholder carried out a two-year rotation experiment of yambased cropping systems repeated twice (2002-2005).

The single-harvest late maturing variety of yam "Kokoro" (Dioscorea rotundata) was grown in all cases as it is one of the most cultivated species in the study area due to its suitability for storage and processing into dried tubers (the so-called chips), flour, and starchy paste (locally called amala). The experiment was conducted with 32 farmers, eight in each site (Miniffi, Gomè, Akpéro, and Gbanlin). For each of them, we used a randomized block design with four replicates and four crop rotation treatments. Plot size was $10 \mathrm{~m} \times 10 \mathrm{~m}$ (total of $1600 \mathrm{~m}^{2}$ per farm). The four crop rotation treatments were as follows: 
- $\quad$ T0 (Control 1): 1-year fallow of Andropogon gayanusyam rotation, which is a common practice in the area. A natural fallow of Andropogon gayanus grass was grown in the first year.

- $\quad$ TM (Control 2): Maize -yam rotation, which is also a common practice in the area. Maize was planted (at $80 \mathrm{~cm}$ $\times 40 \mathrm{~cm}$ ) in April of the first year.

- $\quad$ TMA: Intercropped Aeschynomene histrix with maize-yam rotation. Maize was planted (at $80 \mathrm{~cm} \times 40 \mathrm{~cm}$ ) in April of the first year. Aeschynomene seeds ( $\left.7 \mathrm{~kg} \mathrm{ha}^{-1}\right)$ were mixed with dry sand ( $3 / 4$ sand - $1 / 4$ seeds) and sown two weeks after the maize.

- TMM: Intercropped Mucuna pruriens with maize-yam rotation. Maize was planted (at $80 \mathrm{~cm} \times 40 \mathrm{~cm}$ ) in April of the first year. Mucuna seeds $\left(25 \mathrm{~kg} \mathrm{ha}^{-1}\right)$ were sown at spacing $80 \mathrm{~cm} \times 40 \mathrm{~cm}$ in May six weeks after the maize.

On treatments TM, TMA and TMM, NPK fertilizer (14\% N, 10\% $\mathrm{P}, 11.7 \% \mathrm{~K}$ ) was applied in April 2002 (and 2004) to maize at 100 $\mathrm{kg} \mathrm{ha}^{-1}$ followed by $50 \mathrm{~kg}$ of urea ha-1 $(46 \% \mathrm{~N})$ in June. The maize was harvested in July. The grainless Mucuna and Aeschynomene crops were mowed 140 and 180 days respectively after planting. Organic matter was incorporated in mounds and left on the surface as mulch in October, and then yam was planted directly on these mounds, without mineral fertilization.

\section{Results and Discussions}

When natural fallow and maize as precedents were compared, yam yield was higher after a (short) natural fallow, despite the chemical fertilizers supply on maize. Indeed, the decrease in yam yields was slower year after year after fertilized maize compared to natural fallow but yam yields remained the lowest after maize. This low residual effect of fertilizers on yam is in accordance with farmers beliefs that yam has a poor response to mineral fertilizer applications as well as with the few experiments conducted on this topic in Benin. Under similar conditions to the present research (rainfall, kokoro landrace), Srivastava, Dagbenonbakin and Gaiser (2010) did not find any significant response to mineral fertilizer nor to manure applications on yam cultivated in the central part of Benin (low land use intensity). Gbedolo [6] also reported that experimentation with mineral fertilizers on Benin rarely produced significant results, and that $\mathrm{N}$ application resulted in tubers of low organoleptic quality. Similar lack of response was found in both forest transition and savannah areas in Nigeria after application of a range of mineral and organic fertilizers (Ajayi, Akinrinde and Asiedu 2006). However, many experiments concluded otherwise. In Ghana in a forest transition zone where farmers typically plant yam on newly cleared fields, fertilizer applied in several splits did increase tuber yields by $22 \%$ without reducing the sensory quality of the product [7]. In Trinidad, Chapman [8] obtained a $30 \%$ increase in tuber yield, under the condition that $\mathrm{N}$ application was delayed until three months after planting. Several other works showed positive effects of mineral fertilizers on yam yield $[9,10]$.
Diby et al. [11] in Ivory Coast came to the conclusion that response to fertilizers of both D. alata, D. cayenensis-rotundata are affected by soil properties. Fertilizer application increased dry matter (DM) production of both species in the savannah site but not in the forest site. Diby et al. [2] also showed that the low yields obtained on soils with low organic matter content were not improved by supplying mineral fertilizer. This would lead to the hypothesis that there are forests soils too rich and savanna soils too poor in organic matter for any response to chemical fertilizers and in between a range of moderately depleted soils where a response can be expected $[12,13]$. In the end, the effects of fertilizer supply on yam have to be related to soil organic matter contents and boundary conditions (climate, agro-ecological zone, soil type, cultivation history) as well as to the fertilizer type supplied and its application and to the crop management practices. In all, little research has been conducted so far to interpret the response to fertilizers either applied on yam or here on a precedent crop.

\section{Acknowledgement}

None.

\section{Conflict of Interest}

No conflict of interest.

\section{References}

1. FAOSTAT (2011).

2. Diby LN, Hgaza VK, Tie TB, ASSA A, Carsky R, et al. (2009) Productivity of yams (Dioscorea spp.) as affected by soil fertility. Journal of Animal \& Plant Sciences 5(2): 494-506.

3. Adjei-Nsiah S, Kuyper TW, Leeuwis C Abekoe MK, Giller KE (2007) Evaluating sustainable and profitable cropping sequences with cassava and four legume crops: Effects on soil fertility and maize yields in the forest/savannah transitional agro-ecological zone of Ghana. Field Crop Res 103: 87-97.

4. Sodjadan PK, Toukourou AM, Carsky RJ, Vernier P (2005) Effets des précédentes plantes de couverture sur la production de l'igname en zone de savane au Bénin et au Togo. African Journal of Root and Tuber crops 6(1): 34-40.

5. Agossou V, Igué M (2002) Caractérisation des sols des sites de recherche développement du CRA-Centre: classification dans la base de référence mondiale et actualisation de leur niveau de dégradation, Atelier scientifique Centre (1ére édition) au CRA- Centre, INRAB/MAEP, Savè, Bénin.

6. Gbedolo YM (1986) Factors limiting yam production in Benin. p. 57-60. In ER Terry et al. (ed.) Tropical root crops: Root crops and the African food crisis. Proc Trienn Symp Int Soc Trop Root Crops, $3^{\text {rd }}$, Owerri, Nigeria.

7. Ennin SA, Isaaka RN, Acheampong PP, Numafo M, Owusu Danquah E (2014) Mechanization, fertilization and staking options for environmentally sound yam production. African Journal Agricultural Research 9(29): 2222-30.

8. Chapman EA (1965) Some investigations into factors limiting yields of White Lisbon yams (Dioscorea alata) under Trinidad conditions. Trop Agric 42: 145-151.

9. Cornet D Amadji F, Dossou R, Maliki R, Vernier P (2005) Intérêts des légumineuses herbacées pour une production durable d'igname en Afrique de l'Ouest, in Ozier-Lafontaine, H, Ed, Proceedings of the $41^{\text {th }}$ international meeting of the CFCS, Le Gosier, Guadeloupe.

10. Djokoto RK, Stephens S (1961) Thirty long-term fertilizer experiments under continuous cropping in Ghana, in crop yield and responses to fertilizers and manures. Empire journal of Experimental Agriculture 29: 181-195. 
11. Diby LN, Carsky R, Assa A, Tra TB, Girardin O, et al. (2004) Understanding soil factors limiting the potential yield of yam (Dioscorea spp.). In Proceedings of the $4^{\text {th }}$ International Crop Science Congress, Brisbane Australia.

12. O’Sullivan JN (2010) Yam nutrition: nutrient disorders and soil fertility management. Australian Centre for International Agricultural Research (ACIAR).
13. Srivastava A, Gaiser T (2010) Simulating biomass accumulation and yield of yam (Dioscorea alata) in the Upper Ouémé Basin (Benin Republic) I. Compilation of physiological parameters and calibration at the field scale. Field Crops Research 116: 23-29. 